\title{
EGYES IDŐJÁRÁSI TÉNYEZŐK HATÁSA A BARÁTPOSZÁTA (Sylvia atricapilla) KÖLTÉSI SIKERÉRE
}

\author{
Kiss Csilla $^{1}$, Winkler Dániel ${ }^{1}$, Komlós Mariann ${ }^{1}$, Farkas Roland ${ }^{2}$ \& Gyurácz József ${ }^{3}$ \\ ${ }^{1}$ Soproni Egyetem, Vadgazdálkodási Gerinces Állattani és Intézet \\ University of Sopron, Institute of Wildlife Management and Vertebrate Zoology \\ H-9400 Sopron, Ady E. u. 5. Hungary \\ ${ }^{2}$ Aggteleki Nemzeti Park Igazgatóság \\ H-3758 Jósvafó, Tengerszem oldal 1. Hungary \\ ${ }^{3}$ Eötvös Loránd Tudományegyetem, Savaria Biológiai Intézet, \\ H-9700 Szombathely, Károlyi G. tér 4. Hungary \\ email: csilla.92@hotmail.com; winkler.daniel@uni-sopron.hu; farkasro@yahoo.com; \\ gyuracz.jozsef@sek.elte.hu
}

\begin{abstract}
KISS CS., WinKLER D., KOMlÓs M., FARKAS R. \& GYURÁCZ J.: EFFECT OF METEOROLOGICAL FACTORS ON THE BREEDING SUCCESS OF BLACKCAP (Sylvia atricapilla). Hungarian Small Game Bulletin 13: 255266. http://dx.doi.org/10.17243/mavk.2017.255

The aim of this study was to investigate the relationship between certain meteorological variables and Blackap (Sylvia atricapilla) populations and productivity at a western (Tömörd) and a north-eastern Hungarian (Szalonna) bird ringing station. For the evaluation, CES ringing data for the period 2004-2016 was used. According our results, Blackcap productivity was mainly affected by the minimum temperature of April, beginning of the breeding season. Thus, in case of colder periods, number of successfully fledged young birds decreased significantly. Occasionally, increased capture number of adult breeding Blackaps matched with lower productivity, indicating abundance-determined population regulation.
\end{abstract}

KULCSSZAVAK: barátposzáta, költési időszak, GLM, CES, Tömörd, Szalonna KEY WORDS: Blackcap, breeding season, GLM, CES, Tömörd, Szalonna

\section{BEVEZETÉS}

A madarak monitorozása természetvédelmi szempontból is nagy jelentőséggel bír, amely által lehetővé válik térben és időben reprezentatív módon mérni a természeti állapotban bekövetkező változásokat, nem csak lokálisan, hanem regionálisan vagy akár interkontinentális szinten is.

Egyre több kutatás számol be arról, hogy az utóbbi néhány évtizedben nagy változások következtek be számos madárfaj morfológiájában és fenológiájában (CRICK, 2004; HÜPPOP \& HÜPPOP, 2003; VISSER \& BOTH, 2005; CSÖRGÖ, 2015; KISS et al., 2016a). A klímaváltozás hatására a megváltozott környezeti feltételek miatt módosulhat a fajok földrajzi eloszlása, és ez a változás mind a költő-, mind a telelőterületeken kimutatható (CsÖRGÖ, 2015). Változások mutatkoznak a vonulás időzítésében és fenológiájában, a költés időzítésében, de még a vedlésben is (CRICK \& SPARKS, 1999; BOTH \& VISSER, 2001; CRICK \& SPARKS, 2006; BIADUŃ et al., 2009; Doswald et al., 2009; RoBINSON et al., 2009; DOLENEC \& DOLENEC, 2010). Változások tapasztalhatók a populációk egyedszámában, az egyedek méretében és testtömegében is, ami különbözö lehet még a testvér fajok esetében is (BAILLIE \& PEACH, 1992; HÜPPOP \& HÜPPOP, 2003; CSÖRGÖ et al., 2009). 
Ezek a változások a plasztikusabb viselkedésü rövid- és középtávú vonulóknál erőteljesebben jelentkeznek, hiszen a hosszú távú vonulók erős genetikai kontrol alatt állnak, így lassabban adaptálódnak a megváltozott környezeti feltételekhez (OZAROWSKA \& ZANIEWICZ, 2015).

Az általunk vizsgált barátposzáta (Sylvia atricapilla) a leggyakoribb poszátafajunk (MME, 2017). Főként a fás, bokros élöhelyeket kedveli, sürü aljnövényzetü erdőkben, parkokban, kertekben költ (MULLARNEY, et al., 2005; GYURÁCZ, 2012). Költési időszakban rovarevő, ősszel és télen főként bogyókon él (JORDANO \& HERRERA, 1981; GLUTZ VON BLOTZHEIM \& BAUER, 1991). Többnyire fák alacsonyabb ágaira, bokrokra, vagy sürü aljnövényzetbe építi fészkét (CRAMP, 1992). Évente kétszer költ, először április-májusban, majd június-júliusban (SCHMIDT, 1984).

Kevert parciális vonuló. A különböző területeken élő madarak esetében eltérőek a vonulási úthosszak és a leküzdendő akadályok, ennek következtében alakultak ki az eltérő vonulási stratégiák (CRAMP, 1992, CSÖRGÖ \& GYURÁCZ, 2009). A különböző vonulási stratégiák, a vonulás iránya és a telelő terület is öröklött (CRAMP, 1992). A közép-európai madarak parciális vagy obligát középtávú vonulók. Ezek a madarak a fészkelőterület nyugati és déli részén töltik a telet: Nyugat- és Dél-Európában, illetve Északnyugat-Afrikában a Szahara északi szegélyéig (LÖVEI et al., 1985; CsÖRGÖ \& GYURÁCZ, 2009).

A hazai állomány középtávú vonuló, visszafogások alapján főleg a Mediterráneum keleti, ritkábban középső területein telel. Magyarországon márciustól októberig találkozhatunk vele (CSÖRGÖ \& GYURÁCZ, 2009).

Korábbi elemzéseinkkel bizonyítottuk, hogy egy nyugat-magyarországi (Tömörd) barátposzáta állomány költési sikerére kimutatható hatással van a hömérséklet (GYURÁcZ et al., 2016, KISS et al., 2016b). Jelen tanulmányunkban egy nyugat- (Tömörd) és egy keletmagyarországi állomány (Szalonna) adatainak felhasználásával vizsgáljuk a barátposzáták fogásszáma, költési sikere, valamint a költési időszak időjárása között feltételezett kapcsolatot.

\section{ANYAG ÉS MÓDSZER}

\subsection{VIZSGÁLT TERÜLETEK}

A vizsgálat során két madárgyürüző állomás, a Tömördi Madárvárta és a Bódva-völgyi Madárvonuláskutató és Természetvédelmi Tábor adatainak összehasonlító vizsgálatát végeztük el.

A Tömördi Madárvárta Vas megyében, az Ablánc-patak völgye mentén, a Chernel István Madártani és Természetvédelmi Egyesület által kezelt területen, a tömördi Nagy-tó mellett található. A tavat csak csapadékvíz táplálja, ezért a vízfelület kiterjedése és a mélysége a mindenkori csapadékmennyiség függvényében változik. A feltöltődési folyamatok és a száraz időjárás következtében a tó nyílt vízfelülete 2000 nyarára eltünt. A 2001 őszén elvégzett medertisztítás után újra egyre több csapadék gyült össze a mederben, mely már hosszabb ideig megmaradt (BÁNHIDI, 2002). A területen 1998 óta folynak rendszeres természetvédelmi és madártani vizsgálatok.

A függönyhálók felállításának helyén a növénytársulások alapján négy élőhelytípus különíthető el (KESZEI \& BAUER 1999), amelyek pihenő-, búvó- és táplálkozóhelyet jelentenek a vonuló madarak számára:

- mocsár élőhelytípus

- heterogén gyep élőhelytípus

- töviskés élöhelytípus

- erdő élőhelytípus. 
A Bódva-völgyi Madárvonuláskutató és Természetvédelmi Tábor Szalonna és Perkupa községek között, a Bódva partján található. A madárvárta 1986 óta müködik a Bódva-völgyben. A völgy magyarországi szakasza megközelítőleg É-D irányú. A vizsgálati terület a völgy egy viszonylag szük, 500m széles szakaszán található. A völgyet közrefogó két hegyoldalon zárt cseres-tölgyesekkel és gyertyános tölgyesek a jellemző faállománytípusok. A völgyaljban kaszáló- és mocsárrétek, müvelt és felhagyott szántóföldek, bokorsorok és a Bódva egykor levágott mederszakaszai húzódnak. A vizsgálati terület nagy része két, egymással párhuzamos bokorsor, melyek az egyik hegyoldal lábánál kialakult ligeterdő foltok és cserjések mentén helyezkednek el. A hálók ezekben a bokrosokban vannak felállítva. A bokrosok jellemző növényfajai: fekete bodza (Sambucus nigra), kökény (Prunus spinosa), som (Cornus spp.), hamvas szeder (Rubus caesius), csíkos kecskerágó (Euonymus europaeus) (FARKAS et al., 2014).

\subsection{VIZSGÁLATI MÓDSZEREK}

A madarak befogásához 2,5 m magas, 5 zsebes, 12 m hosszú hálókat használtunk. A gyürüzés ideje alatt a hálókat óránként ellenőriztük. Ellenőrzés során a madarakat óvatosan kiszabadítottuk a hálóból, majd egyesével vászonzsákokba tettük és a gyürüző asztalhoz vittük őket. Faj szerinti meghatározásuk után jelölőgyürü került a lábukra, mely tartalmazza az ország kódját és egy sorszámot. Ezt követően a biometriai adatok megállapítása történt, melyek a gyürüző füzetbe feljegyzésre kerültek más fontos adatokkal együtt (SZENTENDREY et al., 1979).

Az Állandó Ráfordítású Gyürúzés (CES - Constant Effort Sites) célja a költő madarak standardizált keretek között folyó hosszútávú monitoringja, ezáltal a madárpopulációk egyedszámváltozásának és szaporodási sikerének vizsgálata (KARCZA \& MAGYAR, 2009). A CES fontos eleme, hogy a felméréseket minden évben megegyező helyen, állandó hálófelülettel, állandó hálóhelyekkel, rögzített időpontokban, meghatározott időtartamban kell elvégezni, meghatározott elöírás szerint.

A fészkelő állományok vizsgálata költési időszakban (áprilistól júliusig) 9 egymást követő 10 napos periódusban történik. A mintavétel egy adott napon napkeltétől számított 6 órán keresztül tart (BÁLDI et al., 1997).

2004-ben a Tömördi Madárvárta és a Bódva-völgyi Madárvonuláskutató és Természetvédelmi Tábor is csatlakozott a CES-programhoz. Ebben az időszakban Tömördön $13 \mathrm{db}$ hálót használtunk, így összesen $390 \mathrm{~m}^{2}$ hálófelülettel fogtuk be a madarakat, míg Szalonnán 8 hálóval történt a befogás, összesen $240 \mathrm{~m}^{2}$ hálófelületen. Az összehasonlíthatóság miatt a fogási adatokat egységnyi hálófelületre $\left(100 \mathrm{~m}^{2}\right)$, standardizálva adjuk meg $\left(\mathrm{N}_{\mathrm{s}}=\left(\mathrm{N} / \mathrm{A}_{\text {háló }}\right)^{*} 1000\right)$. A költési sikert (kirepült fiatalok aránya = produktivitás) a fiatal (juvenilis $=$ első éves) és öreg (adult $=$ legalább 1 éves madár) egyedek fogásszámából származtattuk: juv/(juv+ad).

A továbbiakban a Tömördön és Szalonnán, 2004 és 2016 között, a CES programban gyüjtött adatsor alapján a barátposzáták fogásszáma, illetve költési sikere és a költési időszak hónapjainak időjárása között kerestünk kapcsolatot. Az időjárási tényezők hatásainak vizsgálatakor a két fent említett madárvártához legközelebb eső, nagyobb meteorológiai állomások 2004-2016 évekre vonatkozó adatait vettük alapul. Ezek alapján a tömördi adatokat a szombathelyi, míg a szalonnai adatokat a miskolci állomás adatsorával vetettük össze (NNDC, 2017). Korábbi vizsgálatok alapján, az időjárási tényezők megválasztásánál elsősorban azt vettük figyelembe, hogy mely paraméterek lehetnek hatással a barátposzáták 
költési sikerére. Ezek alapján a havi középhőmérsékletet $\left(\mathrm{T}_{\text {mean }}\right)$, a minimum és maximum hőmérsékletet $\left(\mathrm{T}_{\min } ; \mathrm{T}_{\max }\right)$ és a csapadékösszeget $(\mathrm{P})$ emeltük ki.

A két vizsgálati terület fogásszáma, a fiatal és öreg madarak fogásszáma, valamint a produktivitás és az öreg madarak fogásszáma között feltételezett kapcsolatot Pearson-féle korrelációs számítással ellenőriztük. A hőmérséklet és a produktivitás között feltételezett kapcsolat ellenőrzésére általános lineáris modellt (GLM) használtunk. Ez a modell lehetővé teszi több független változó (pl. minimum és maximum hőmérsékleti értékek) együttes hatásának egyidejű vizsgálatát. A statisztikai értékeléseket a Past statisztikai program segítségével végeztük el (HAMMER et al., 2001).

\section{EREDMÉNYEK}

\subsection{A VIZSGÁLT TERÜLETEK IDŐJÁRÁSA}

A két állomás, Miskolc és Szombathely Walter-Lieth klímadiagramjait az 1. és 2. ábra szemlélteti, amelyeken jól megfigyelhetők a Péczeli-féle felosztás (PÉCZELY, 1979) alapján is feltételezhetö különbségek és hasonlóságok.

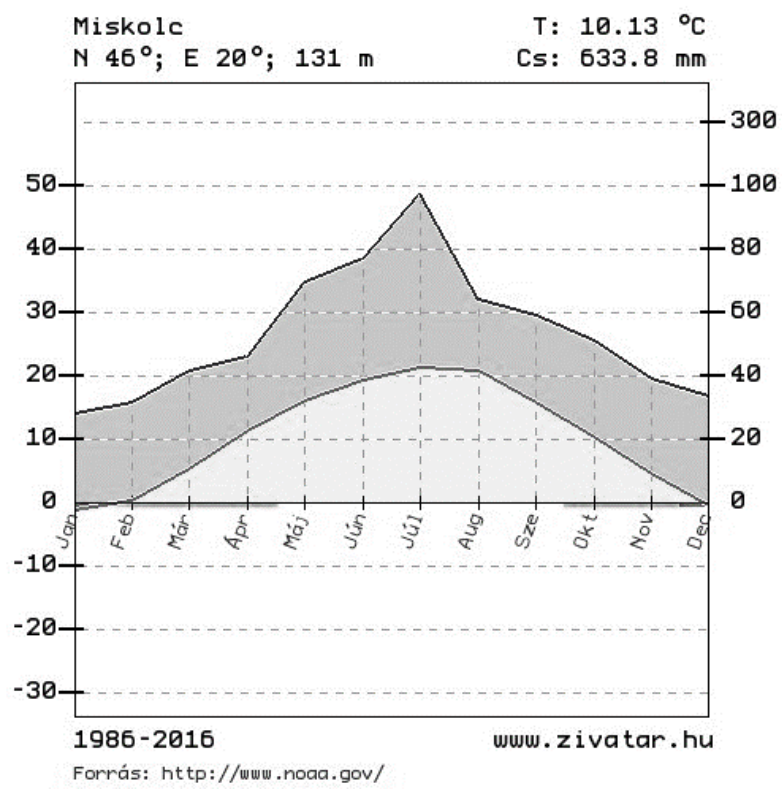

1. ábra: Miskolc Walter-Lieth diagrammja

Figure 1: Walter-Lieth climate diagram (Miskolc)

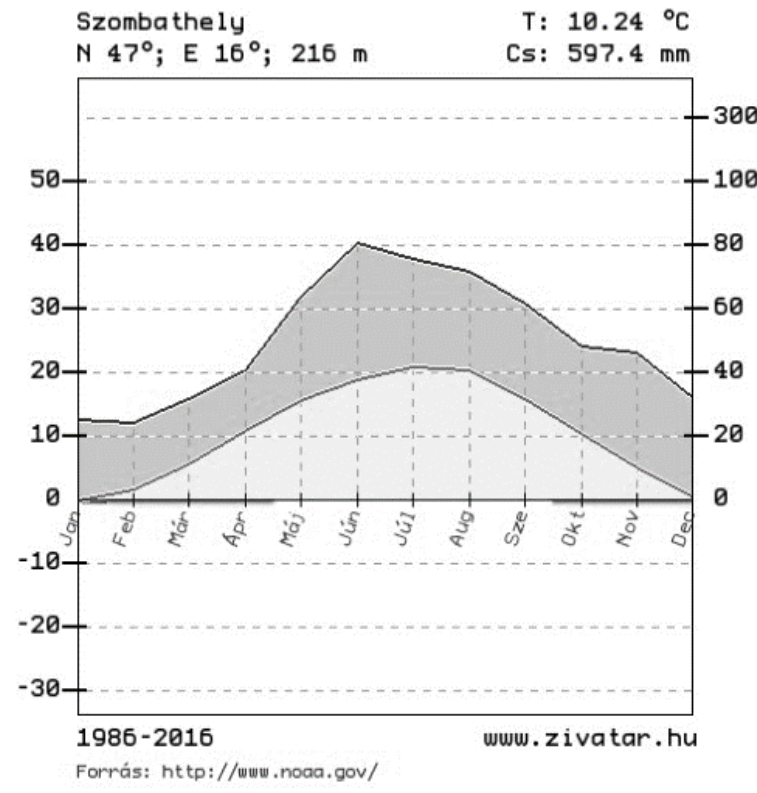

2. ábra: Szombathely Walter-Lieth diagrammja

Figure 2: Walter-Lieth climate diagram (Szombathely)

Minkét állomás szubhumid kategóriába sorolható teljes évben. A csapadék minimum télen, a maximum nyáron fordul elö. Ezt a látszólagos görbét követi a hőmérséklet éves járása is. Különbség van az éves csapadékösszegben és átlaghőmérsékletben is. Miskolc magasabb átlag hömérséklettel, és nagyobb csapadékösszeggel rendelkezik. Ezen kívül a legtöbb csapadék Miskolcon júliusban esik, míg Szombathelyre a júniusi csúcs jellemző.

$\mathrm{Az}$ egyes évek átlaghőmérséklete ugyan eltérő lehet, de az utóbbi 30 év értékeit tekintve nincs jelentős különbség a két állomás között (Szombathely: $10,2^{\circ} \mathrm{C}$; Miskolc: $10,7^{\circ} \mathrm{C}$ ), Mindkét esetben emelkedő trend figyelhető meg (3. és 4. ábra). 


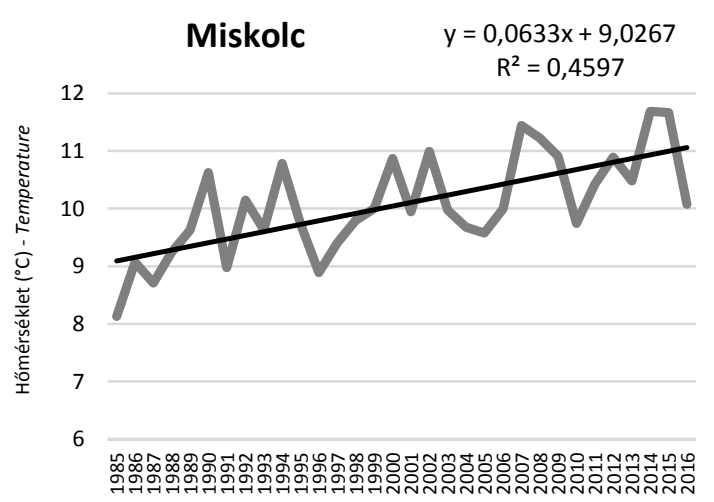

3. ábra: Miskolc éves átlaghőmérsékletei 1985-2016

Figure 3. Mean temperature in Miskolc (1985-2016)

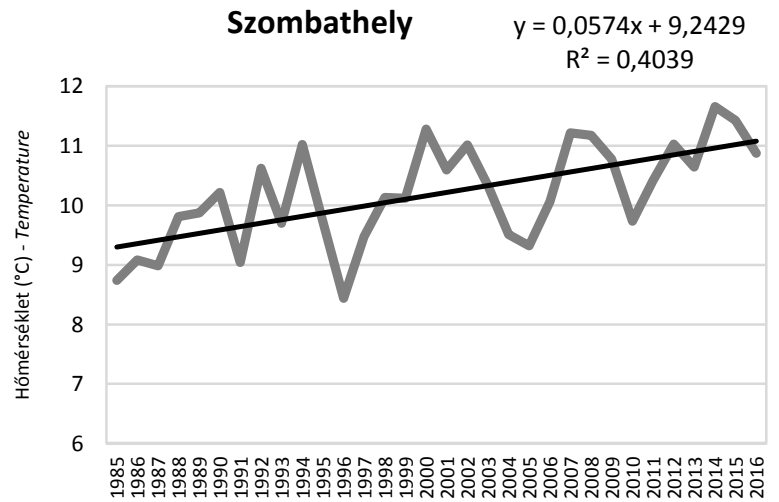

4. ábra: Szombathely éves átlaghőmérsékletei 1985-2016

Figure 4. Mean temperature in Szombathely (1985-2016)

A minimum és maximum hőmérsékletekről ugyanez elmondható, annyi különbséggel, hogy Miskolcon a minimum hömérsékletek valamivel alacsonyabbak a Szombathelyen mért értékeknél.

A barátposzáták szaporodási sikerére négy hónap időjárása gyakorolhat közvetlen hatást: április, május, június és július. Az alábbi diagramok (5-8. ábra) ezen hónapok időjárását szemléltetik a vizsgált időszakban.

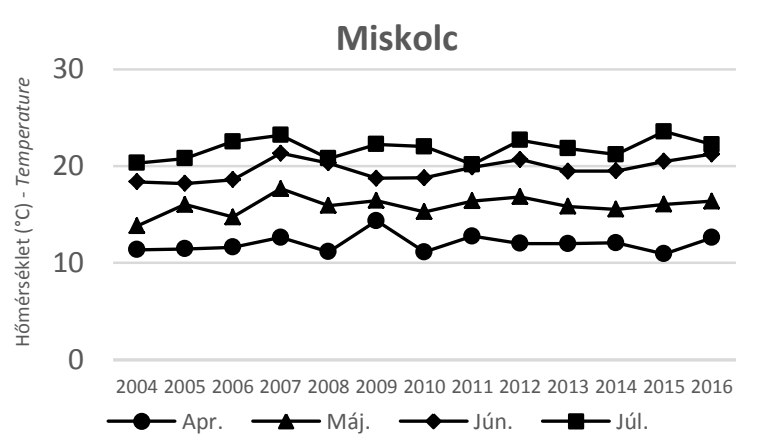

5. ábra: A költési időszak átlaghőmérséklete Figure 5: Mean temperature during the breading season

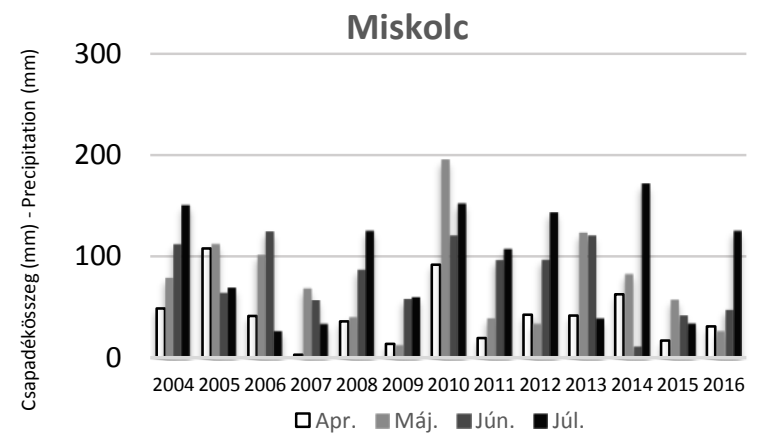

6. ábra: A költési időszak csapadékmennyisége Figure 6: Precipitation during the breading season

Miskolcon a költési időszak átlaghőmérséklete $17,29^{\circ} \mathrm{C}$ volt 2004 és 2016 között. A leghüvösebb év 2004 volt $15,97^{\circ} \mathrm{C}$-os átlaghőmérséklettel, a legmelegebb $\left(18,71^{\circ} \mathrm{C}\right)$. Igazán kiugró érték csak 2009 áprilisában volt, ahol $14,36^{\circ} \mathrm{C}$ volt a havi átlaghőmérséklet, ezt a 5. ábra is jól szemlélteti. Ez az érték majdnem $3^{\circ} \mathrm{C}$-al magasabb, mint az adott időszak áprilisi átlaghőmérséklete $\left(11,9^{\circ} \mathrm{C}\right)$.

$\mathrm{Az}$ átlagos csapadékösszeg $299 \mathrm{~mm}$ volt, de itt már nagyobb eltéréseket is tapasztalhatunk (6. ábra). A legtöbb csapadék $(561 \mathrm{~mm})$ 2010-ben hullott, míg a legkevesebb (152 mm) 2014-ben. Hónapokra lebontva az adott időszakot elmondható, hogy a legkevesebb csapadék (3 mm) 2007 áprilisában esett, míg a legcsapadékosabb hónap 2010 májusa volt, összesen 196 mm csapadékkal, ami több mint fele a vizsgált időszak átlagának.

A költési időszakra vonatkozó Szombathelyi hőmérsékleti adatokat a 7. ábra mutatja be. Az adott időszakban $16,8^{\circ} \mathrm{C}$ volt az átlaghőmérséklet. Miskolchoz hasonlóan a leghidegebb 
év $\left(15,1^{\circ} \mathrm{C}\right) 2004$ volt, a legmelegebb $\left(18,3^{\circ} \mathrm{C}\right)$ pedig 2007 , amikor szinte minden hónapban az átlaghoz képest magasabb hőmérsékleti értékeket kaptunk.

A két állomás csapadékösszegeiben már nagyobb különbségek mutatkoznak (8. ábra). Szombathelyen 2004 és 2015 között költési időszakban az átlagos csapadékösszeg mindössze $250 \mathrm{~mm}$ volt, még a kiugró értékek is sokkal alacsonyabbak Miskolchoz képest. A legtöbb csapadék (390 mm) 2008-ban hullott, a legkevesebb $(149 \mathrm{~mm})$ pedig 2007-ben. Az időszak legcsapadékosabb hónapja 2008 júniusa $(179 \mathrm{~mm})$, a legszárazabb $(0,3 \mathrm{~mm})$ pedig Miskolchoz hasonlóan - 2007 áprilisa volt.

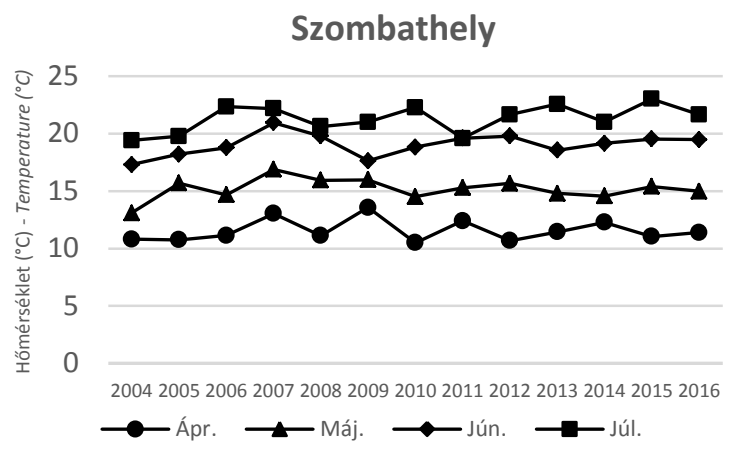

7. ábra: A költési időszak átlaghőmérséklete Figure 7: Mean temperature during the breading season

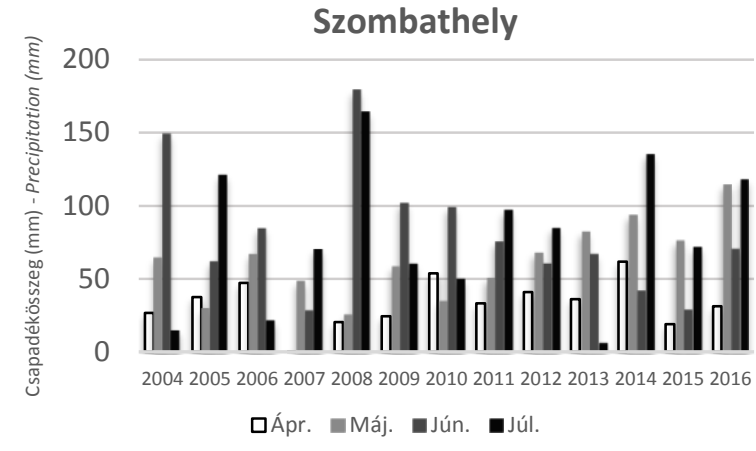

8. A költési időszak csapadékmennyisége Figure 8: Precipitation during the breading season

\subsection{FOGÁSI EREDMÉNYEK}

Tömördön a vizsgált 13 év alatt összesen 678 egyedet, Szalonnán 597-et fogtunk meg költési időszakban, évente változó egyedszámmal. A $100 \mathrm{~m}^{2}$ hálófelületre standardizált adatokat az 1. és 2. táblázat tartalmazza.

1. táblázat: A barátposzáták fogására vonatkozó, standardizált adatok (Tömörd) Table 1: Standardized data of Blackcap captures (Tömörd)

\begin{tabular}{lcccc}
\hline & $\begin{array}{c}\text { fiatalok } \\
\text { juveniles }\end{array}$ & $\begin{array}{c}\text { öregek } \\
\text { adults }\end{array}$ & $\begin{array}{c}\text { összes fogás } \\
\text { total capture }\end{array}$ & $\begin{array}{c}\text { produktivitás } \\
\text { productivity }\end{array}$ \\
\hline $\mathbf{2 0 0 4}$ & 2,05 & 8,72 & 10,77 & 0,19 \\
$\mathbf{2 0 0 5}$ & 1,28 & 7,95 & 9,23 & 0,14 \\
$\mathbf{2 0 0 6}$ & 4,10 & 10,00 & 14,10 & 0,29 \\
$\mathbf{2 0 0 7}$ & 4,10 & 5,90 & 10,00 & 0,41 \\
$\mathbf{2 0 0 8}$ & 8,97 & 6,67 & 15,64 & 0,57 \\
$\mathbf{2 0 0 9}$ & 4,36 & 5,90 & 10,26 & 0,43 \\
$\mathbf{2 0 1 0}$ & 2,82 & 8,46 & 11,28 & 0,25 \\
$\mathbf{2 0 1 1}$ & 10,51 & 8,72 & 19,23 & 0,55 \\
$\mathbf{2 0 1 2}$ & 2,31 & 13,33 & 15,64 & 0,15 \\
$\mathbf{2 0 1 3}$ & 3,08 & 9,23 & 12,31 & 0,25 \\
$\mathbf{2 0 1 4}$ & 12,31 & 5,13 & 17,44 & 0,71 \\
$\mathbf{2 0 1 5}$ & 6,15 & 12,56 & 18,72 & 0,33 \\
$\mathbf{2 0 1 6}$ & 4,87 & 4,36 & 9,23 & 0,53 \\
\hline
\end{tabular}


2. táblázat: A barátposzáták fogására vonatkozó, standardizált adatok (Szalonna) Table 2: Standardized data of Blackcap captures (Szalonna)

\begin{tabular}{lcccc}
\hline & $\begin{array}{c}\text { fiatalok } \\
\text { juveniles }\end{array}$ & $\begin{array}{c}\text { öregek } \\
\text { adults }\end{array}$ & $\begin{array}{c}\text { összes fogás } \\
\text { total capture }\end{array}$ & $\begin{array}{c}\text { produktivitás } \\
\text { productivity }\end{array}$ \\
\hline $\mathbf{2 0 0 4}$ & 6,25 & 6,67 & 12,92 & 0,48 \\
$\mathbf{2 0 0 5}$ & 9,58 & 6,25 & 15,83 & 0,61 \\
$\mathbf{2 0 0 6}$ & 6,67 & 16,25 & 22,92 & 0,29 \\
$\mathbf{2 0 0 7}$ & 10,83 & 13,33 & 24,17 & 0,45 \\
$\mathbf{2 0 0 8}$ & 11,25 & 10,00 & 21,25 & 0,53 \\
$\mathbf{2 0 0 9}$ & 9,17 & 9,58 & 18,75 & 0,49 \\
$\mathbf{2 0 1 0}$ & 4,58 & 15,00 & 19,58 & 0,23 \\
$\mathbf{2 0 1 1}$ & 11,25 & 11,25 & 22,50 & 0,50 \\
$\mathbf{2 0 1 2}$ & 3,75 & 12,92 & 16,67 & 0,23 \\
$\mathbf{2 0 1 3}$ & 5,00 & 6,67 & 11,67 & 0,43 \\
$\mathbf{2 0 1 4}$ & 12,08 & 8,33 & 20,42 & 0,59 \\
$\mathbf{2 0 1 5}$ & 7,92 & 15,00 & 22,92 & 0,35 \\
$\mathbf{2 0 1 6}$ & 9,58 & 9,58 & 19,17 & 0,50 \\
\hline
\end{tabular}

A befogott fiatal és öreg madarak mennyisége 2004 és 2016 között nem mutatott szignifikáns növekvő trendet Tömördön és Szalonnán sem.

A Tömördön és Szalonnán befogott fiatal madarak mennyisége között szoros pozitív korreláció van $(\mathrm{r}=0,71 ; \mathrm{p}=0,01)$, míg az öreg madarak és a produktivitás esetében nincs szoros kapcsolat.

A befogott öreg és fiatal madarak száma között nincs lényeges kapcsolat, míg a befogott öreg madarak száma és a produktivitás között lényeges negatív korreláció van mindkét helyen (Tömörd: $r=-0,64 ; p=0,02$ ), Szalonna: $r=-0,76, p=0,00$ ).

Annak ellenére, hogy a két állomás produktivitási értékei közti hasonlóság nem szignifikáns, a $100 \mathrm{~m}^{2}$ hálófelületre standardizált produktivitás értékek mindkét területen hasonlóan alakultak a vizsgált idöszakban (11. ábra), a 2005-ös év kivételével a változás azonos irányú volt. Jól megfigyelhetők a nagyobb minimumok $(2010,2012,2015)$ és maximumok (2008, 2011, 2014) közel szinkron alakulása. A ciklikusan ismétlődő produktivitási értékek hátterében azonban nem csak hőmérsékleti, hanem egyéb okok is állhatnak (pl. táplálékkínálat, betegségek, predáció).

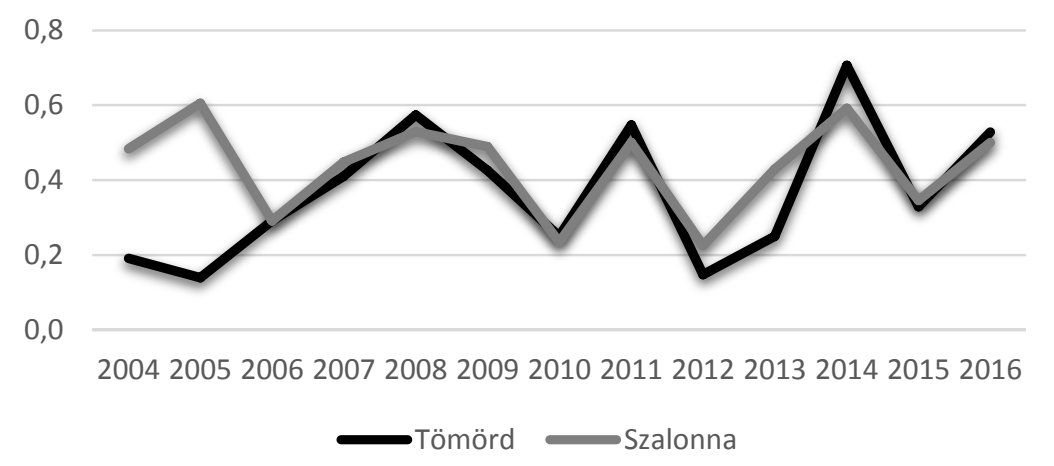

11. ábra: A barátposzáta produktivitásának változása a két vizsgálati területen (Tömörd és Szalonna) Figure 11: Change of Blackcap productivity in the two studied area (Tömörd and Szalonna) 


\subsection{AZ IDŐJÁRÁS ÉS A BARÁTPOSZÁTA ADATOK ÖSSZEFÜGGÉSEI}

Ezt követően az idojjárási és barátposzáta adatokat korreláltattuk, amely során a következő szignifikáns kapcsolatokat sikerült kimutatni (3. táblázat):

3. táblázat: Időjárási változók ( $T_{\text {mean }}$ : középhőmérsékelt, $T_{\text {min }}$ : minimum hőmérséklet, $\mathbf{P}=$ csapadékösszeg) és a barátposzáta adatok (Ad: adult, Juv: fiatal, Pro: produktivitás) összefüggései

Table 3: Correlations between weather variables $\left(T_{\text {mean }}\right.$ : mean temperature, $T_{\text {min }}$ : minimum temperature, P: precipitation) and Blackcap data (Ad: adult, Juv: juvenile, Pro: productivity)

\begin{tabular}{ccccc}
\hline & & & $\mathrm{r}$ & $\mathrm{p}$ \\
\hline április & Szombathely-Tömörd & $\mathrm{T}_{\text {mean }}-\mathrm{Ad}$ & $-0,60$ & 0,03 \\
& Szombathely-Tömörd & $\mathrm{T}_{\text {mean }}-$ Pro & 0,60 & 0,03 \\
& Szombathely-Tömörd & $\mathrm{T}_{\text {min }}-\mathrm{Juv}$ & 0,60 & 0,03 \\
& Szombathely-Tömörd & $\mathrm{T}_{\text {min }}-$ Pro & 0,58 & 0,03 \\
\multirow{4}{*}{ május } & Miskolc-Szalonna & $\mathrm{T}_{\min }-\mathrm{Juv}$ & $-0,60$ & 0,03 \\
& Miskolc-Szalonna & $\mathrm{T}_{\min }-\mathrm{Pro}$ & $-0,58$ & 0,04 \\
& Miskolc-Szalonna & $\mathrm{T}_{\min }-\mathrm{Juv}$ & $-0,60$ & 0,03 \\
& Miskolc-Szalonna & $\mathrm{P}-\mathrm{Juv}$ & $-0,67$ & 0,01 \\
július & Miskolc-Szalonna & $\mathrm{P}-$ Pro & $-0,54$ & 0,05 \\
& Szombathely-Tömörd & $\mathrm{P}-\mathrm{Juv}$ & 0,57 & 0,04 \\
& Szombathely-Tömörd & $\mathrm{P}-$ Pro & 0,59 & 0,03 \\
\hline
\end{tabular}

Az áprilisi hőmérséklet és a fiatalok éves fogása között nem, míg az áprilisi hömérséklet és a produktivitás között lényeges pozitív kapcsolat mutatkozott Tömördön. Szalonnán a korrelációk nem voltak szignifikánsak. Az áprilisi hőmérséklet és az öreg madarak éves fogása között szignifikáns negatív korreláció adódott Tömördön, Szalonnán nincs lényeges kapcsolat a miskolci értékekkel. Az áprilisi minimum hőmérséklet és az öreg madarak között egyik területen sem mutatható ki szignifikáns kapcsolat. Tömördön az áprilisi minimum hőmérséklet és a fiatal barátposzáták száma, valamint a produktivitás között lényeges pozitív kapcsolat van, míg Szalonnán nem találtunk szignifikáns kapcsolatot.

A májusi, júniusi és júliusi középhőmérséklet és a barátposzáta adatok között egyik állomáson sem volt lényeges kapcsolat. A májusi és júniusi minimum hőmérséklet és a fiatal barátposzáták száma között Szalonnán erős negatív kapcsolat van, valamint a májusi minimum hőmérséklet és a szalonnai produktivitás is erős negatív korrelációt mutat. Tömördön a korrelációk nem szignifikánsak.

A kora tavaszi csapadékösszeg nincs kapcsolatban a barátposzáták állományváltozásaival. Szalonnán a júniusi csapadékösszeg és a fiatalok, valamint a produktivitás között negatív kapcsolat van, míg Tömördön a júliusi csapadékösszeg és a fiatal madarak száma, illetve a produktivitás között szignifikáns pozitív kapcsolat mutatkozott.

Az általános lineáris modell (GLM) segítségével végzett vizsgálat eredményeit a 4. táblázat tartalmazza. A független változók egyidejű hatásának vizsgálata esetén az áprilisi minimum hőmérséklet és a produktivitás között mindkét állomáson pozitív kapcsolatot mutattunk ki. Tehát a barátposzáta első költésének idején a hideg időjárás negatívan befolyásolja a kirepülés sikerességét.

A májusi minimum hőmérséklet és a produktivitás között ellentétes, szignifikáns kapcsolat volt megfigyelhető, a júliusi minimum hőmérsékletek és a produktivitás között pedig pozitív kapcsolat adódott. 


\section{4. táblázat: A produktivitás, valamint a minimum és maximum havi hőmérsékletek közötti kapcsolat elemzésének eredményei, általánosított lineáris modellel (GLM)}

Table 4: Results of the GLM (generalized linear model) analysis on the effect of maximum and minimum temperature on Blackcap productivity

\begin{tabular}{ccccccc}
\hline & & & Coeff. & $\mathrm{SE}$ & $\mathrm{t}$ & $\mathrm{p}$ \\
\hline Szombathely-Tömörd & $\mathrm{T}_{\min }$ & április & 0,04 & 0,01 & 3,72 & 0,005 \\
& & május & $-0,07$ & 0,02 & $-3,34$ & 0,01 \\
& & június & $-0,01$ & 0,02 & $-0,67$ & 0,52 \\
& & július & 0,06 & 0,02 & 2,55 & 0,03 \\
& \multirow{2}{*}{$\mathrm{T}_{\max }$} & április & $-0,03$ & 0,02 & $-1,16$ & 0,28 \\
& & május & 0,02 & 0,02 & 0,77 & 0,46 \\
& & június & 0,009 & 0,03 & 0,30 & 0,77 \\
Miskolc-Szalonna & július & $-0,000$ & 0,03 & $-0,002$ & 0,99 \\
& \multirow{2}{*}{$\mathrm{T}_{\min }$} & április & $-0,01$ & 0,03 & $-0,51$ & 0,05 \\
& & május & $-0,05$ & 0,03 & $-2,03$ & 0,07 \\
& & június & $-0,01$ & 0,02 & $-0,65$ & 0,53 \\
& július & 0,04 & 0,05 & 0,76 & 0,47 \\
& \multirow{2}{*}{$\mathrm{T}_{\max }$} & április & $-0,01$ & 0,03 & $-0,45$ & 0,66 \\
& & május & 0,02 & 0,02 & 1,24 & 0,25 \\
& június & $-0,01$ & 0,03 & $-0,25$ & 0,81 \\
& július & $-0,01$ & 0,03 & $-0,32$ & 0,76 \\
\hline
\end{tabular}

\section{DISZKUSSZIÓ}

A barátposzáta kirepülési sikerére jelentős hatással van a fészkelési időszak elejére jellemző tavaszi hőmérséklet. Enyhébb tavaszi időjárás esetén több fióka hagyja el sikeresen a fészket (LEECH \& CRICK, 2007), ez azonban helyi változatosságot is mutathat. A hüvösebb tavaszi időjárás növeli az első költések fióka-mortalitását. Ennek a sürüség-független szabályozásnak egyik feltételezhető oka lehet a fészkek nyitott jellege, ami a hideg miatti mortalitás növekedése mellett a nagyobb predáció lehetőségét is jelenti (CRAMP \& PERRINS, 1992). A felnőtt madarak ilyenkor több időt töltenek a fészken kotlással, illetve a fiókák melengetésével (termoreguláció), ennek következtében kevesebbet tudnak emiatt etetni. (PEARCE-Higgins \& YALDEN, 2004; HoYe \& ForCHAMMER, 2008).

A fészkelö öreg madarak nagyobb éves fogása esetén sokszor kisebb a produktivitás, ami sürüségfüggő populációszabályozásra utal. Egyes területeken a több fészkelő madár átlagosan kevesebb fiókát tud felnevelni a megnövekvő intrapopulációs forráskompetíció miatt. A klímaváltozás következtében egyes táplálék rovarfajok populációi csökkenő trendet mutatnak, ami szintén hatással lehet az erdei énekesmadárfajok, így a barátposzáta költési sikerére is (JONES et al., 2003; BOTH \& VISSER, 2005). A költési siker, a kompetíció mértéke élöhelyfüggő (WEIDINGER, 2000), erre következtethetünk azon eredményeinkből is, mely szerint a két vizsgálati területen tapasztalt produktivitási értékek évenkénti alakulása között nincs szignifikáns korreláció.

2004 és 2016 között a havi átlaghőmérsékletek szignifikáns növekvő tendenciát mutattak, de a sűrüség-független és sürüségfüggő populáció-szabályozás következtében a fiatal és öreg madarak éves fogásának enyhe, nem szignifikáns növekedése alapján a barátposzáta vizsgált populációit stabilnak minősíthetjük. 
Csapadékösszegre vonatkozó szignifikáns korrelációkat csak a második költés esetében tudtunk kimutatni, ahol a júniusi negatív irányú kapcsolat a fészekpusztulások miatti mortalitást jelezheti, míg a júliusi pozitív kapcsolat a táplálékbőséggel hozható összefüggésbe (JONES et al., 2003). Egy angliai hosszú távú, több fajra vonatkozó vizsgálat (PEARCEHigGins et al., 2015) szintén kimutatta, hogy egyes énekesmadárfajok érzékenysége a hőmérsékletre jobban meghatározta a költési sikert, mint a csapadékösszeg mértéke.

\section{KÖSZÖNETNYILVÁNÍTÁS}

Köszönjük a Tömördi Madárvárta és a Bódva-völgyi Madárvonuláskutató és Természetvédelmi Tábor önkéntes munkatársainak a terepi adatgyüjtésben végzett munkáját.

\section{IRODALOMJEGYZÉK}

BAILlIE, S. \& PEACH, W. (1992): Population limitation in Palearctic-African migrant passerines. Ibis 134: 120-132. http://doi.org/10.1111/j.1474-919X.1992.tb04742.x

BÁldi A., MosKÁT CS. ÉS SZÉP T. (1997): Nemzeti Biodiverzitás-monitorozó Rendszer IX. Madarak. In: Horváth F., Korsós Z., KovÁCSNÉ LÁNG E. \& MATSKÁSI I. (szerk.): Nemzeti Biodiverzitás-monitorozó Rendszer. Magyar Természettudományi Múzeum. Budapest

BÁNHIDI P. (2002): Tömördi Természetvédelmi és Madárgyürüző Tábor (2002). Cinege 7: 18-21.

BIADUŃ, W., KITOWSKI, I. \& FILIPIUK, E. (2009): Trends in the arrival dates of spring migrants in Lublin (E Poland). Acta Ornithologica 44: 89-94. http://dx.doi.org/10.3161/000164509X464920

BOTH, C., VISSER, M. E. (2001): Adjustment to climate change is constrained by arrival date in a longdistance migrant bird. Nature 411: 296-298. http://doi.org/10.1038/35077063

CSÖRGÖ T. (2009): Miért és hogyan vonulnak a madarak? In: CsÖRGÖ T. KARCZA Zs., HALMOS G., Magyar G., Gyurácz J., SzÉp T., BAnKovics A., SChMidT A. \& SCHMidT E. (szerk.): Magyar Madárvonulási Atlasz. Kossuth Kiadó, Budapest.

CsÖRGÖ T. (2015): Madarak és az éghajlatváltozás. National Geographic 13(11): 104-105.

CSÖRGÖ T., GYURÁCZ J. (2009): Barátposzáta In: CsÖRGÖ T. KARCZA Zs., HALMOs G., MAGYAR G., GyurÁCz J., SzÉP T., BAnKovics A., SChMidT A. \& SCHMidT E. (szerk.): Magyar Madárvonulási Atlasz. Kossuth Kiadó, Budapest.

CSÖRGÖ T., HARnOS A., KovÁCS Sz. \& NAGY K. (2009): A klímaváltozás hatásainak vizsgálata hosszútávú madárgyürüzési adatsorok elemzésével. Természetvédelmi Közlemények 15: 1-12.

CrAMP, S. ed. (1992): Handbook of the Birds of Europe, the Middle East and North Africa. The Birds of the Western Palearctic. Vol. VI. Warblers. Oxford University Press, Oxford.

CRICK, H.Q.P. (2004): The impact of climate change on birds. Ibis 146: 48-56. http://doi.org/10.1111/j.1474-919X.2004.00327.x

CRICK, H.Q.P. \& SPARKS, T. H. (1999): Climate change related to egg-laying trends. Nature 399: 423424. http://doi.org/10.1038/20839

CRICK, H.Q.P. \& SPARKS, T.H. (2006): Changes in the phenology of breeding and migration in relation to global climate change. Acta Zoologica 52: 154-157.

DoleneC, Z. \& DOLENEC, P. (2010): Response of the blackcap (Sylvia atricapilla L.) to temperature change. Polish Journal of Ecology 58: 605-608.

Doswald, N., Willis, S.G., Collingham, Y.C., Pain, D.J., Green, R.E. \& Huntley, B. (2009): Potential impacts of climatic change on the breeding and non-breeding ranges and migration distance of European Sylvia warblers. Journal of Biogeography 36(6): 1194-1208. http://doi.org/10.1111/j.1365-2699.2009.02086.x

FARKAS R., HUBER A. \& GÁTI E. (2014): Fészkelő és vonuló madárfajok állományainak vizsgálata a Bódva-völgyben. ANP füzetek XII. Aggteleki Nemzeti Park Igazgatóság, Jósvafö 248 p. 
GYURÁCZ J. (2012): Barátposzáta (Sylvia atricapilla). In: FARAGÓ S. (szerk.): Nyugat-Magyarország fészkelö madarainak elterjedési atlasza. Nyugat-magyarországi Egyetem Kiadó, Sopron. pp. 178.

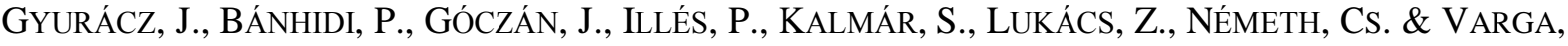
L. (2016): Temperature and precipitation effects on breeding productivity of some passerines $-\mathrm{a}$ multivariate analysis of constant effort mist-netting data. Biologia - Section Zoology 71(11): 1298-1303. https://doi.org/10.1515/biolog-2016-0149

GlutZ VON BlotZHeIM, U. N. \& BAUER K. M. (1991): Handbuch der Vögel Mitteleuropas. Bd. 12. Passeriformes. Teil 2. Sylviidae. Aula-Verlag, Wiesbaden.

HAMMER, R., HARPER, D.A.T. \& RYAN, P. D. (2001): PAST: Paleontological Statistics Software Package for Education and Data Analysis. Palaeontologia Electronica 4(1): 9 pp.

HøYe, T.T. \& FORCHAMMER, M.C. (2008): Phenology of High-Arctic arthropods: effect of climate on spatial, seasonal and inter-annual variation. Advances in Ecological Research 40: 299-324. http://doi.org/10.1016/S0065-2504(07)00013-X

HÜPOPP, O. \& HÜPOPP, K. (2003): North Atlantic Oscillation and timing of spring migration in birds, Proceedings of the Royal Society B: Biological Sciences 270: 233-240.

JONES, J., DORAN, P.J. \& HOLMES, R.T. (2003): Climate and food synchronize regional forest bird abundances. Ecology 84(11): 3024-3032. http://doi.org/10.1890/02-0639

JORDANO, P. \& HERRERA, C.M. (1981): The frugivorous diet of Blackcap Sylvia atricalpilla wintering in southern Spain. Ibis 123: 502-507. http://doi.org/10.1111/j.1474-919X.1981.tb04055.X

KARCZA Zs. \& MAGYAR G. (2009): A madárgyürüzés története. In: CsÖRGÖ T., KARCZA Zs., Halmos G., Magyar G., Gyurácz J., Szép T., Bankovics A., Schmidt A., Schmidt E. (szerk.): Magyar madárvonulási atlasz. Kossuth Kiadó. Budapest, 48-62.

Kiss Cs., BÁNhidi P., LukÁcs Z., KALMÁR S., Winkler D. \& GYURÁCZ J. (2016a): A csilpcsalpfüzike (Phylloscopus collybita Vieillot, 1817) populációdinamikájának vizsgálata a Tömördi Madárvártán a 2000-2014-es időszakban. Savaria Egyetemi Központ Tudományos Közleményei XXI. Természettudományok 16: 209-220.

Kiss CS., LUKÁCS Z., BÁNHIDI P., IllÉs P., KOSZORÚS P., KALMÁR S., WinKLER D. \& GYURÁCZ J. (2016b): A költési időszak időjárásának hatása a barátposzáta (Sylvia atricapilla) tömördi állományára. Cinege 21: 22-25.

KESZEI B. \& BAUER N (1999): A tömördi Nagy-tó és környékének növényvilága. Vasi Szemle 53(1): $97-110$.

LEECH, D.I. \& CRICK, H.Q.P. (2007): Influence of climate change on the abundance, distribution and phenology of woodland bird species in temperate regions. Ibis 149(s2): 128-145. http://dx.doi.org/10.1111/j.1474-919X.2007.00729.x

LÖVEI, G., SceBbA, S \& MiLONE, M. (1985): Migration and wintering of the Blackcap Sylvia atricapilla on a Mediterranean island. Ringing and Migration 6: 39-44. http://dx.doi.org/10.1080/03078698.1985.9673852

MAGYAR MADÁRTANI ÉS TERMÉSZETVÉDELMI EGYESÜLET (2017): Magyarország madarai: Barátposzáta. http://www.mme.hu/magyarorszagmadarai/madaradatbazis-sylatr Letöltés dátuma: 2017-01-02

Mullarney, K., Svensson, L., ZetTerströM, D. \& GRANT, P.J. (2005): Madárhatározó. Park Könyvkiadó, Budapest, $400 \mathrm{pp}$.

NNDC (2016): National Climatic Data Center. http://www.ncdc.noaa.gov/ Letöltés dátuma: 2016-1110.

OZAROWSKA, A. \& ZANIEWICZ, G. (2015): Temporal trends in the timing of autumn migration of short- and long-distance migrating Blackcaps (Sylvia atricapilla). Ornis Fennica 92: 144-152.

PEARCE-Higgins J.W. \& YALDEN D.W. (2004): Habitat selection, diet, arthropod availability and growth of a moorland wader: the ecology of European Golden Plover Pluvialis apricaria chicks. Ibis 146(2): 335-346. http://doi.org/10.1111/j.1474-919X.2004.00278.x

Pearce-Higgins, J.W., Eglington, S.M., Martay, B. \& Chamberlain, D.E. (2015): Drivers of climate change impacts on bird communities. Journal of Animal Ecology 84(4): 943-954. http://doi.org/10.1111/1365-2656.12364

PÉCZELY GY. (1979): Éghajlattan. Tankönyvkiadó Vállalat, Budapest. 
Robinson, R.A., CRICK, H.Q.P., LEARMONTH, J.A., MACLEAN, I.M.D., THOMAS, C.D., BAIRLEIN, F., ForChHAMMER, M.C., Francis, C.M., GILl, J.A., GODLEY, B.J., HARWOOD, J., HAYS, G.C., Huntley, B., Hutson, A.M., Pierce, G.J., Rehfisch, M.M., Sims, D.W., Santos, M.B., SPARKS, T.H., STROUD, D.A. \& VISSER, M.E. (2008) Travelling through a warming world climate change and migratory species. Endangered Species Research 7: 87-99. http://doi.org/10.3354/esr.00095

SCHMIDT E. (1984): Barátka poszáta. In: HARASZTHY L. (szerk.): Magyarország fészkelő madarai. Natura, Budapest-Dabas. pp. 188-189.

SZENTENDREY G., LÖVEI G. \& KÁLLAY GY. (1979): Az „Actio Hungarica” madárgyürüző tábor mérési módszerei. Állattani Közlemények 66(1-4): 161-166.

VISSER, M.E. \& BOTH, C. (2005): Shifts in phenology due to global climate change: the need for a yardstick. Proceedings of the Royal Society B: Biological Sciences 272: 2561-2569.

WEIDINGER, K. (2000): The breeding performance of Blackcap Sylvia atricapilla in two types of forest habitat. Ardea 88: 225-233. 